урбанонимы по-прежнему успешно локализуют объект в городской черте, однако определить его точное местоположение человеку, плохо с ним знакомому, практически невозможно. Особенно это проблематично в больших городах, в которых топонимы типа Школьная улициа и Заводская улица являются малоинформативными, поскольку подобных объектов в населенном пункте может быть несколько.

DOI 10.31168/7996-2700-3.103

\title{
Мачей Рак
}

Ягеллонский университет

Краков, Польша

maciej.rak@uj.edu.pl

\section{К вопросу о культуремах - диалектных, общепольских, славянских}

Культурема - это этнолингвистическая единица, ключевое слово; его план выражения представлен одной лексемой, а план содержания настолько богат и специфичен, что благодаря культуремам можно понять особенности данной национальной, этнической или региональной общности. Через культуремы сообщество определяет свою идентичность; из-за частой непереводимости представляющие их лексемы этноцентричны (нередко они входят в автостереотип); они являются словами, транслирующими коллективную память.

Культуремы обычно функционируют как компоненты фразеологизированных высказываний и появляются в клишированных текстах фольклора, народной поэзии, региональной литературы и в саморефлексивных высказываниях. Чаще всего они выражаются существительным, которое может быть связано с универсальной и оригинальной чертой человеческого мышления - видеть мир в категории вещей [см.: Rak, 2015a, 13; 2015b; 2017].

Как известно, этнолингвистика в Польше сосредоточилась на описании языковой картины мира, языкового стереотипа и культурного символа [Bartmiński, 2005], закрепленных в основном в народном материале. Концепция культурем, разработанная в книге «Kulturemy (C) Рак M., 2019 
podhalańskie» [Rak, 2015a], также касается зависимости между диалектом (точнее, двумя его уровнями - лексическим и текстовым) и народной культурой и, несомненно, попадает в сферу этнолингвистических исследований. Имеем ли мы дело с народной, национальной или сравнительной этнолингвистикой? Материал, подвергаемый анализу, конечно, позволяет отнести монографию к области народной этнолингвистики, но специфика культурем означает, что следует также говорить о сравнительной этнолингвистике. На самом деле отправной точкой является специфика мышления гуралей, в результате чего в работе можно обнаружить элементы этносоциологии, этнопсихологии и этнофилософии.

Целью этнолингвистических словарей является реконструкция традиционного образа мира и человека. В свою очередь, цель изучения славянских культурем должна заключаться в том, чтобы указать, что нас идентифицирует и, в конечном счете, отличает от других жителей Европы (не славян). Несомненно, этот подход также выявит различия между Slavia Orthodoxa и Slavia Romana.

Bartmiński J. Folklorystyka, etnonauka, etnolingwistyka - sytuacja w Polsce // Literatura Ludowa. 2005. T. 49. № 6. S. 5-13.

Rak M. Kulturemy podhalańskie. Kraków, 2015a. (Biblioteka LingVariów. T. 19). Rak M. Co to jest kulturem? // LingVaria - 10. 2015b. Z. 2 (20). S. 305-316.

Rak M. Kulturemy - nowa perspektywa badań etnolingwistycznych // Tekst i dyskurs - Text und diskurs. 2017. № 10. S. 217-227. 